\title{
A CARACTERIZAÇÃO DO BRASIL COMO PARAÍSO FISCAL ANTE AS REGRAS DE TRANSPARÊNCIA FISCAL INTERNACIONAL E O JULGAMENTO DA CONSTITUCIONALIDADE DA LEI COMPLEMENTAR N.․ 105/2001
}

\author{
BRAZIL'S CHARACTERIZATION AS A "TAX HEAVEN" TAKING INTO ACCOUNT \\ THE INTERNATIONAL TRANSPARENCY RULES AND THE RULING ABOUT THE \\ CONSTITUTIONALITY OF COMPLEMENTARY LAW Nº 105/2001
}

\author{
${ }^{1}$ Liziane Angelotti Meira \\ ${ }^{2}$ Ricardo Victor Ferreira Bastos
}

\begin{abstract}
RESUMO
A proteção ao sigilo fiscal e bancário é aspecto de grande importância dentro do ordenamento jurídico nacional, pois ambos são definidos como cláusulas pétreas na Constituição Federal de 1988. Essa proteção desencadeia grande discussão jurídica quando confrontadas com a Lei Complementar $n^{\circ}$. 105/01, principalmente, coma as regras que permitem a obtenção de informações sobre transações bancárias pela Fazenda Pública. A grande importância que essa troca de informação possui, atualmente, no cenário mundial, está em discussão nas cinco ações diretas de inconstitucionalidade em curso no Supremo Tribunal Federal, sendo que o tema ganhou força com a aplicação da legislação FATCA em nosso ordenamento jurídico. O resultado do julgamento poderá colocar o Brasil numa situação peculiar dentro do contexto internacional que defende e recomenda a possibilidade de troca de informações entre instituições financeiras e o fisco, podendo o país ser caracterizado como um regime tributário privilegiado ou mesmo como um paraíso fiscal se aplicadas as regras defendidas pela OCDE.
\end{abstract}

Palavras-chave: Sigilo bancário e fiscal, Lc 105/01. constitucionalidade, Troca de informações

\begin{abstract}
The protection of financial secrecy aspect is of great importance within the national legal system, as both are defined as immutable clauses in the 1988 Constitution. This protection triggers major legal argument when confronted with $\mathrm{LC} \mathrm{n}^{\circ}$. $105 / 01$, mainly eat the rules for obtaining information on banking transactions by the Treasury. The great importance that this information exchange currently has on the world stage, is under discussion in the five ongoing direct action of unconstitutionality in the Supreme Court, and the issue has gained momentum with the implementation of FATCA legislation in our legal system. The outcome of the trial will put Brazil in a peculiar position within the international context that supports and recommends the possibility of exchange of information between tax authorities and financial institutions, the country can be characterized as a privileged tax regime or even as a tax haven is the applied rules advocated by the OECD.
\end{abstract}

Keywords: Banking secrecy and tax secrecy, Lc 105/01, Constitutionality, Information exchange

\footnotetext{
${ }^{1}$ Possui doutorado em Direito pela Pontifícia Universidade Católica de São Paulo, PUC - SP, (Brasil). É Professora da PósGraduação Stricto Sensu em Direito da Universidade Católica de Brasília UCB - DF, (Brasil). E-mail: lizianemeira@gmail.com

${ }^{2}$ Mestre em Direito Tributário pela Universidade Católica de Brasília - UCB - DF, (Brasil). É professor de Pós Graduação, instrutor e desenvolvedor de cursos internos no BRB, Banco de de Brasília - DF, (Brasil). E-mail: ricardovfb@gmail.com
} 


\section{INTRODUÇÃO}

O presente artigo tem como objetivo principal analisar o cenário jurídico dos sigilos fiscal e bancário ante a Lei Complementar $n^{\circ}$. 105/01. Pretende-se fazer correlação entre essas garantias e as regras de troca de informações defendidas no âmbito internacional, de modo a se interligar todos esses pontos com os efeitos que podem ser produzidos com o julgamento das diversas ações que questionam a constitucionalidade da LC 105/01.

A importância das eventuais decisões das cinco Ações Direta de Inconstitucionalidade e da que já foi proferida no Recurso Extraordinário ${ }^{1}$ relaciona-se com o efeito que elas podem gerar na caracterização do Brasil como um paraíso fiscal ou como um ente de regime fiscal favorecido, tendo em vista regras de direito tributário internacional que preveem as trocas de informações entre instituições financeiras e o fisco, principalmente pelas disposições contidas no relatório denominado de Harmful Tax Competition pela OCDE e nas regras defendidas pelo "Fórum Global da Transparência"

O ponto inicial refere-se ao fato de que a questão do sigilo bancário no Brasil tem como pano de fundo o seu enquadramento como um direito fundamental previsto no art. $5^{\circ}$, inc. X e XII da Constituição Federal, o que torna a análise desse tema bem peculiar no sistema jurídico. Assim, o âmbito de aplicação de tal norma constitucional é o vetor central da análise acerca da constitucionalidade ou não das leis que versam sobre troca de informação entre instituições financeiras e o fisco.

A troca de informações é uma atividade de cooperação internacional que reflete no grau de transparência com que as diversas operações financeiras ou comerciais são tratadas dentro de um determinado ordenamento jurídico e que está sendo tratado como regra obrigatória no combate a evasão de divisas, lavagem de dinheiro e nas mais diversas fraudes tributárias. O que precisa ser delimitado inicialmente, é que essas regras acerca de troca de informações refletem sobremaneira no trato de determinado ente soberano como sendo ou não passível de enquadramento como um paraíso fiscal ou como um ente com regime fiscal favorecido ou regime fiscal prejudicial.

A importância de tal tema está no fato de que toda discussão acerca da troca de informações que circunda a Lei Complementar $n^{\circ}$. 105/2001 tem um fundo constitucional, tendo em vista o impacto das questões relacionadas ao sigilo de dados e na vida privada das pessoas. As cinco ações diretas de inconstitucionalidade mencionadas referem-se aos 
dispositivos da Lei Complementar, bem como, por arrastamento, dos decretos a ela correlatos, cabendo ressaltar a existência de um Recurso Extraordinário (RE 389808) já decidido pelo Supremo Tribunal Federal no qual foi preservado o sigilo bancário e restringida a aplicação da LC $n^{\circ} .105 / 01$, o que impediu a Receita Federal do Brasil de ter acesso direto a dados bancários da pessoa jurídica recorrente.

Esse cenário constitucional e internacional, a importância que a troca de informações possui no contexto mundial atual, captaneado pelas regras da Organização para a Cooperação e desenvolvimento Econômico (OCDE), pela existência de inúmeros tratados sobre dupla tributação (TDT) que se ocupam de questões relacionadas a troca de informações entre entes soberanos, de modo que se possa criar um cenário internacional favorável a transparência das relações econômicas sejam elas internacionais ou mesmo as que já são nacionalizadas, o que culminou, recentemente, com a legislação americana do Foreign Account Tax Compliance Act (FATCA) que prevê a celebração de acordos internacionais dos Estados Unidos com diversos países para que haja a remessa de informações daqueles considerados pela legislação como us persons.

\section{O SIGILO BANCÁRIO E FISCAL NO BRASIL}

É importante que se entenda como se caracteriza o sigilo fiscal e bancário no Brasil, para que se tenha subsídios e seja possível analisar tais aspectos no contexto internacional. É a partir do entendimento do que ocorre no Brasil que se pode discutir o enquadramento das regras nacionais com o que é praticado pelo mundo.

\subsection{CONCEITO E AMPLITUDE DOS SIGILOS BANCÁRIO E FISCAL}

A definição de sigilo, seja qual a espécie for, encontra diversas dificuldades de precisão, tendo em vista a amplitude da palavra possui na da língua portuguesa e dentro do ordenamento jurídico nacional. Em síntese, tem-se que a palavra, "sigilo" significa segredo, ou seja, aquilo que não pode ser revelado, ou o que pode ser conhecido apenas por algumas pessoas restritas. Diversas acepções permeiam essa palavra, de modo que as adjetivações que a acompanham tratam de separar e delimitar qual sigilo ela está se referindo: tem - se o sigilo bancário, o fiscal, o profissional, o de informações, etc.

Em relação aos sigilos bancário e físcal, objeto de nossa análise, observa-se uma gama de definições doutrinárias e até judiciais, cabendo ressaltar a dificuldade que as instituições financeiras e o próprio fisco possuem de determinar em o seu conceito, sua 
definição e seu âmbito de aplicação. No nosso ordenamento jurídico, os sigilos bancário e fiscal correspondem a garantias constitucionais que tem como desdobramento na intimidade e na vida privada, sendo tais aspectos tratados nos incisos X e XII do art. $5^{\circ}$ da Constituição Federal como se vê adiante:

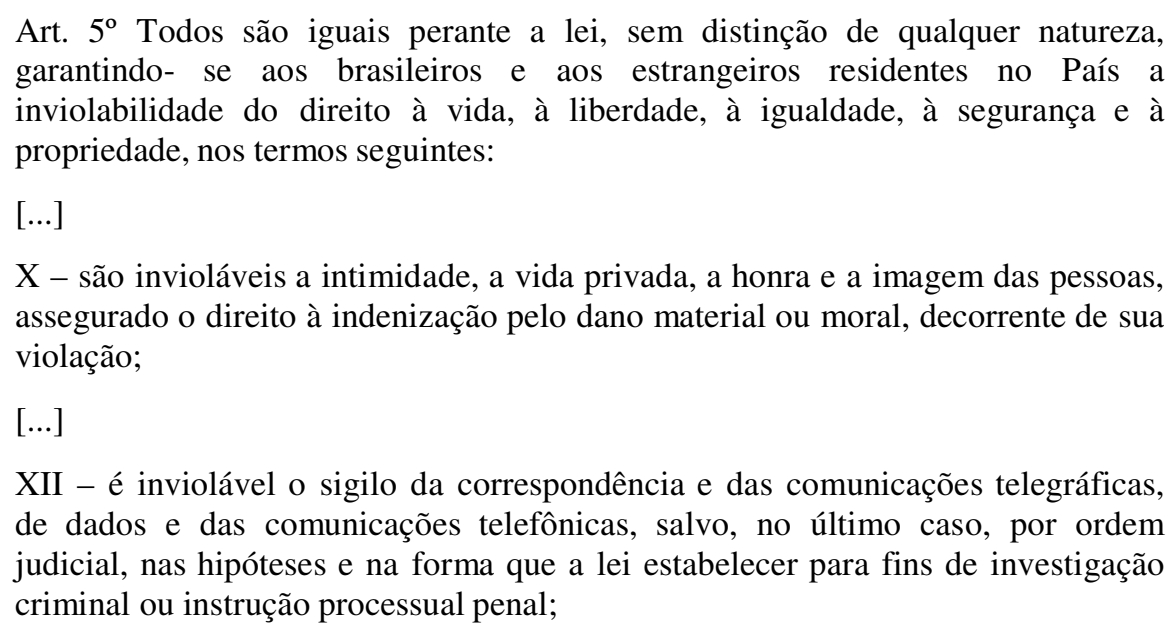

De maneira bem sucinta, tem-se que o sigilo bancário refere-se a vedação às instituições financeiras de divulgar dados relacionados à movimentação financeira de seus clientes, levando em conta as disposições da Lei $n^{\circ}$. 4.595/64 e a LC $n^{\circ}$. 105/01. Tal sigilo tem como maior ponto de discussão a abrangência de seu alcance, de modo que não se encontra firmada a amplitude dessa vedação de fornecimento de informações, se apenas seriam referentes a movimentações financeiras em conta corrente ou mesmo outras questões quanto a imagem de clientes no interior de agencia, por exemplo.

Já o sigilo fiscal, fundamentado nos artigos 198 e 199 do Código Tributário Nacional, refere-se à proibição direcionada ao fisco de que divulgue informações relacionadas à situação econômica ou mesmo financeira de quem seja sujeito passivo² da relação tributária ou mesmo de pessoas estranhas a essa relação sobre a situação de seus negócios ou atividades. Acerca dos sigilos em questão, CARRAZZA (2013, p. 553) ${ }^{3}$ assevera a grande importância da proteção ao sigilo fiscal e bancário:

\footnotetext{
${ }^{2}$ È imperioso destacar que o conceito de sujeito passivo preconizado no art. 198 refere-se aquele que possua dados junto ao fisco, devendo ser incluída a noção de responsável tributário no caso em questão, o que envolve os sujeitos relacionados nos artigos 134 e 135 do CTN. dificuldades financeiras (comprováveis por constantes saldos bancários negativos), etc.
} 
Com efeito, a Constituição, como já dito, garantiu a inviolabilidade da privacidade e o sigilo de dados. Para evitá-los, assegurou também o sigilo das informações bancárias, seja das constantes das instituições financeiras, seja das existentes na própria Fazenda Pública. No que andou bem, pois, por meio da análise e divulgação dos dados bancários deixa-se ao desabrigo a intimidade da pessoa; fica fácil saber quais suas preferencias políticas (v.g., na hipótese de ter feito uma doação de campanha a um partido, qual sua religião (pelo eventual donativo a uma igreja), com quem se relaciona, quais suas diversões habituais, que lugares frequenta, s está passando por

Em trecho elucidativo acerca do âmbito de definição de tais sigilos, o Superior Tribunal de Justiça no Resp n ${ }^{\circ}$. 1349363/SP ponderou que:

\begin{abstract}
(...)
Em verdade, sob o manto do sigilo fiscal podem estar albergadas informações a respeito da situação financeira da pessoa (inclusive informações bancárias) e sob o manto do sigilo bancário podem estar albergadas informações também contidas na declaração de bens. Basta ver que as informações requisitadas pela Secretaria da Receita Federal junto às instituições financeiras deixam de estar protegidas pelo sigilo bancário (arts. $5^{\circ}$ e $6^{\circ}$ da LC n. 105/2001) e passam à proteção do sigilo fiscal (art. 198, do CTN). Sendo assim, o fato é que a mesma informação pode ser protegida por um ou outro sigilo, conforme o órgão ou entidade que a manuseia (..)
\end{abstract}

O Superior Tribunal de Justiça no Resp nº 1197444/RJ também seguiu nessa linha, determinando a exigência de fundamentação especifica para que seja decretada a quebra do sigilo bancário de réus em ação penal:

RECURSO ESPECIAL. DIREITO ADMINISTRATIVO. IMPROBIDADE ADMINISTRATIVA. MEDIDA CAUTELAR. QUEBRA DE SIGILO FISCAL E BANCÁRIO. NOTIFICAÇÃO PRÉVIA. INEXIGIBILIDADE EM CASOS DE URGÊNCIA MANIFESTA. DECISÃO QUE CONCEDE A MEDIDA EXTREMA DE FORMA GENÉRICA, SEM A NECESSÁRIA ANÁLISE INDIVIDUALIZADA DA SITUAÇÃO DE CADA RÉU, CAPAZ DE JUSTIFICAR A NECESSIDADE DA MEDIDA CAUTELAR. RECURSO PROVIDO.

1. (...)

2. Na presente demanda, contudo, o Tribunal de origem, de forma genérica, manteve a decisão que deferiu a quebra do sigilo bancário e fiscal de todos os réus, sem, contudo, analisar a situação específica do ora recorrente, individualizando os atos de cada réu que caracterizariam situação excepcional capaz de justificar a necessidade da medida cautelar.

3. Com efeito, caberia ao douto Magistrado a quo fundamentar o deferimento da quebra de sigilo bancário com as razões do seu convencimento quanto à existência de indícios de prova acerca da plausibilidade jurídica do pedido (fumus boni iuris) relativa a cada réu.

4. Recurso Especial provido para determinar o retorno dos autos para o Juízo a quo para que aprecie o pedido cautelar de forma individualizada, conforme entender de direito.

No mesmo sentido o Supremo Tribunal Federal no Mandado de Segurança nº. 22934 entendeu não ser permitido a violação ao sigilo bancário pelo Tribunal de Contas da União: 
EMENTA: MANDADO DE SEGURANÇA. TRIBUNAL DE CONTAS DA UNIÃO. QUEBRA DE SIGILO BANCÁRIO. IMPOSSIBILIDADE. SEGURANÇA CONCEDIDA. O Tribunal de Contas da União, a despeito da relevância das suas funções, não está autorizado a requisitar informações que importem a quebra de sigilo bancário, por não figurar dentre aqueles a quem o legislador conferiu essa possibilidade, nos termos do art. 38 da Lei 4.595/1964, revogado pela Lei Complementar 105/2001. Não há como admitir-se interpretação extensiva, por tal implicar restrição a direito fundamental positivado no art. $5^{\circ}, \mathrm{X}$, da Constituição. Precedente do Pleno (MS 22801, rel. min. Menezes Direito, DJe-047 de 14.03.2008.) Ordem concedida.

Assim, é imperioso observar que tanto o sigilo fiscal quanto o bancário possuem proteção de grande relevância, devendo, qualquer medida que decrete a quebra desse sigilo ou a restrição de sua proteção, ser tratada como situação excepcional, cabendo ressaltar a necessidade de interpretação restritiva acerca das disposições que excepcionam o sigilo. Cabe ressaltar que tais garantias fundamentais não possuem caráter absoluto, como preconiza o próprio texto constitucional, sendo permitido a quebra de sigilo quando em xeque outros princípios ou garantias constitucionais, sempre se balizando por princípios como proporcionalidade e razoabilidade, conforme a técnica da ponderação de valores constitucionais.

\subsection{EVOLUÇÃO LEGISLATIVA DAS EXCEÇÕES AO SIGILO FISCAL E BANCÁRIO}

A questão infralegal do sigilo bancário teve tratamento iniciado com as disposições contidas na lei no . 4.595/64, "Lei do Sistema Financeiro Nacional”, a qual possui status de Lei Complementar, tendo em vista o teor do art. 192 da Constituição Federal de 1988. Tal dispositivo legal, em seu art. 38 (revogado pela Lei Complementar $n^{0} 105$, de 2001), dispunha sobre o dever de sigilo por parte das instituições financeiras, bem como sobre as respectivas exceções.

Esse diploma legal previa a requisição de informações e excepcionava o sigilo mediante solicitação realizada pelo Poder Judiciário, pelo Poder Legislativo, e por agentes fiscais tributários do Ministério da Fazenda e dos Estados, quando houvesse processo instaurado e os dados fossem considerados indispensáveis pela autoridade competente.

$\mathrm{Na}$ sequência, tem-se o próprio Código tributário Nacional, lei $\mathrm{n}^{\circ}$. 5172/65, recepcionada como Lei complementar desde a constituição de 1967, status mantido com a promulgação da Constituição Federal de 1988. O CTN que trata do assunto em seus artigos 197 a 199 quando cuida da Administração Tributária. 
Em 10 de janeiro de 2001, foram editadas as Leis Complementares $n^{\circ} 104$ e 105, responsáveis pela introdução no ordenamento jurídico da permissão para a realização de intercâmbio de informações sigilosas no âmbito da Administração Pública, bem como da Administração Pública Federal comEstados estrangeiros, para fiscalização e investigação de atividades relacionadas com a prática de ilícitos, excepcionando a questão do sigilo bancário e fiscal.

No âmbito do processo civil brasileiro, bem como no âmbito do processo tributário tem-se outra exceção à proibição de quebra do sigilo bancário: quando o Superior Tribunal de Justiça chancelou a possibilidade de consulta a numerários e o consequente bloqueio via sistema BACENJUD de valores em conta corrente de quem esteja sendo executado em procedimento executivo fiscal, ainda que não sejam esgotados os meios de busca de outros bens. $^{4}$

A legislação pátria vem se enriquecendo de dispositivos que, no intuito de manutenção da ordem econômica, tributária, ou mesmo para evitar fraudes, permitem a flexibilização dos sigilos fiscal e bancário, de modo a aumentar o poder de fiscalização das Fazendas estaduais, municipais, distritais e federais, o que corrobora a tendência de troca de informações entre entes diversos na busca de coibir a sonegação de tributos e aumentar a eficiência da administração tributária.

A legislação que tratou da CPMF previa em seu art $11, \S 2^{\circ}$ que:

As instituições responsáveis pela retenção e pelo recolhimento da contribuição prestarão à Secretaria da Receita Federal as informações necessárias à identificação dos contribuintes e os valores globais das respectivas operações, nos termos, nas condições e nos prazos que vierem a ser estabelecidos pelo Ministro de Estado da Fazenda.

4 Entendimento fixado pela Corte Especial do Superior Tribunal de Justiça, no julgamento do REsp. 1.112.943/MA, sob o rito do art. 543-C do CPC e da Resolução 8/STJ, realizado em 15.09.2010, da relatoria da ilustre Ministra NANCY ANDRIGHI. 
A controvérsia que é foco de nossa discussão é constitucionalidade das disposições contidas na Lei Complementar $n^{\text {o. }} 105$, de 201 e nos Decretos $n^{\circ}$. 4489, de 20/02 e 4545, de 2002 que regulamentam dispositivos da lei. A controvérsia se concentra nos artigos $5^{\circ}$ e $6^{\circ}$ ${ }^{5}$ dessa Lei, os quais consistem no cerne das polêmicas e questionamentos junto ao Supremo Tribunal Federal.

\section{O FOREIGN ACCOUNT TAX COMPLIANCE ACT (FATCA) E SEU IMPACTO ÂMBITO DA TROCA DE INFORMAÇÕES}

Nesse contexto das trocas de informações entre entes soberanos ao redor do mundo, observa-se que há diversos instrumentos no que se refere a essa situação, sendo que muitos são em matéria tributária e conhecidos como Tax Informationm Exchange Agreement ou simplesmente por sua sigla TIEA, existindo mais de 500 conforme informa TAVLORARO (2012, p. 5) ao redor do mundo.

Seguindo essa tendência, Brasil e EUA também buscam viabilizar esse intercambio de informações, por meio da celebração de um TIEA ${ }^{6}$. Por meio do decreto legislativo $n^{\circ}$. 211/2013 o Congresso Nacional aprovou o texto do TIEA celebrado entre o Brasil e os EUA o qual foi promulgado pela presidência da República por meio do decreto $\mathrm{n}^{\circ}$. 8003/2013, definindo o objeto do acordo no artigo 1 nos seguintes termos:

\footnotetext{
5 Art. $5^{\mathrm{o}} \mathrm{O}$ Pōer Executivo disciplinará, inclusive quanto à periodicidade e aos limites de valor, os critérios segundo os quais as instituições financeiras informarão à administração tributária da União, as operações financeiras efetuadas pelos usuários de seus serviços. $\S 1^{\mathrm{O}}$ Consideram-se operações financeiras, para os efeitos deste artigo: I - depósitos à vista e a prazo, inclusive em conta de poupança; II - pagamentos efetuados em moeda corrente ou em cheques; III - emissão de ordens de crédito ou documentos assemelhados; IV - resgates em contas de depósitos à vista ou a prazo, inclusive de poupança; V - contratos de mútuo; VI - descontos de duplicatas, notas promissórias e outros títulos de crédito; VII aquisições e vendas de títulos de renda fixa ou variável; VIII - aplicações em fundos de investimentos; IX - aquisições de moeda estrangeira; $\mathrm{X}$ - conversões de moeda estrangeira em moeda nacional; XI - transferências de moeda e outros valores para o exterior; XII - operações com ouro, ativo financeiro; XIII - operações com cartão de crédito; XIV - operações de arrendamento mercantil; e XV - quaisquer outras operações de natureza semelhante que venham a ser autorizadas pelo Banco Central do Brasil, Comissão de Valores Mobiliários ou outro órgão competente. § $2^{\mathrm{O}}$ As informações transferidas na forma do caput deste artigo restringir-se-ão a informes relacionados com a identificação dos titulares das operações e os montantes globais mensalmente movimentados, vedada a inserção de qualquer elemento que permita identificar a sua origem ou a natureza dos gastos a partir deles efetuados. $\S 3^{\mathrm{o}}$ Não se incluem entre as informações de que trata este artigo as operações financeiras efetuadas pelas administrações direta e indireta da União, dos Estados, do Distrito Federal e dos Municípios. $\S 4^{\mathrm{o}}$ Recebidas as informações de que trata este artigo, se detectados indícios de falhas, incorreções ou omissões, ou de cometimento de ilícito fiscal, a autoridade interessada poderá requisitar as informações e os documentos de que necessitar, bem como realizar fiscalização_ou auditoria para a adequada apuração dos fatos. $\S 5^{\mathrm{O}}$ As informações a que refere este artigo serão conservadas sob sigilo fiscal, na forma da lēgislação em vigor.

6 Celebrado em Brasília, no dia 20 de março de 2007, o "Acordo entre o Governo da República Federativa do Brasil e o Governo dos Estados Unidos da América para o intercâmbio de informaçōes relativas a tributos". Pelo Brasil, foi firmado pelo Secretário da Receita Federal — Jorge Antonio Deher Rachid e pelos EUA por seu Embaixador no Brasil — Clifford Michael Sobel.
} 
As Partes assistir-se-ão mediante o intercâmbio de informações que possam ser pertinentes para a administração e o cumprimento de suas leis internas concernentes aos tributos visados por este Acordo, inclusive informações que possam ser pertinentes para a determinação, lançamento, execução ou cobrança de tributos em relação a pessoas sujeitas a tais tributos, ou para a investigação ou instauração de processo relativo a questões tributárias de natureza criminal. As Partes assistir-se-ão mediante o intercâmbio de informações a pedido conforme o Artigo $\mathrm{V}$ e por outras formas conforme acordado pelas autoridades competentes segundo o Artigo X, em conformidade com os termos deste Acordo.

Aspecto de grande importância dentro do contexto mundial nos últimos anos e que ilustra a importância das discussões tratadas em relação a troca de informações, refere-se a legislação dos Estados Unidos denominada de Foreign Account Tax Compliance Act (FATCA). Tal diploma legal está sendo debatido de modo muito intenso por todo o mundo, tendo em vista a necessidade de os países se adequarem à legislação americana sobre transparência e combate a sonegação, evasão fiscal.

O FATCA $^{7}$ está inserido dentro do próprio Código Tributário dos EUA dentro o Capítulo 4 que é intitulado de "taxes to enforce reporting on certain foreign accounts" e subdividido em quatro parágrafos ou seções:

Essa legislação consiste num conjunto de normas criadas nos Estados Unidos (EUA) em março de 2010 com objetivo principal de combater a evasão de divisas ou sonegação fiscal, tendo por base a remessa de informações por instituições financeiras estrangeiras (FFIS) a Administração tributária dos Estados Unidos, através de diversas alterações dentro do código tributário norte americano. Em artigo sobre o tema Wilson Faria e Alessandra Rocha ${ }^{9}$, ensinam que essa preocupação se intensificou :
(...)
após as revelações do Swiss Bankimg Scandal em 2010, onde foi revelado que, ao que tudo indica, muitos FAT CATs estavam escondidos em investimentos não declarados e, portanto, evitando o recolhimento dos tributos devidos sobre as contas localizadas em localidades, como Suíça. Ilhas Cayman, Cingapura e Hong Kong. Conforme os detalhes do escãndalo começaram a aparecer, as autoridades americanas foram surpreendidas com o escopo da evasão fiscal que estava escondida por detrás destas operações financeiras estrangeiras (fora dos EUA). O Governo americano então concluiu que o sistema fiscal americano não seria suficiente para desencorajar os FAT CATs a aplicar seus investimentos em contas secretas (não passíveis de identificação) de bancos estrangeiros. O principal objetivo do FATCA é impor aos bancos estrangeiros a colheita de informações que o Governo americano precisa das "US persons"

\footnotetext{
7 O FATCA integra o que o direito americano chama de HIRE (Hiring Incentives to Restore Employment Act), que se caracteriza como leis dos EUA publicadas no ano de 2010, tendo sido regulamentado de forma definitiva no ano de janeiro de 2013

${ }^{8}$ Legal institute law. U.S. Code Subtitle A - Income Taxes. Disponível em: https://www.law.cornell.edu/uscode/text/26/subtitle-A. Acesso em: 28 de abr. de 2015 .

9 FARIA, Wilson Rodrigues; ROCHA, Alessandra M Gonsales. O combate internacional à evasão fiscal - como FATCA pode afetar as isntituições financeiras brasileiras. Disponível em: http://whathappensin.com.br/wp- content/uploads/2013/09/artigo1.pdf. Acesso em 20 de abr. de 2014.
} 
Em seu artigo acerca do tema, trazem lição curiosa sobre a nomeclatura FATCA utilizada para designação da legislação em questão: "Não é coincidência que a palavra FATCA se assemelha a 'FAT CAT', tradução literal de 'gato gordo' uma expressão usada para descrever pessoas ricas americanas que poderiam não estar cumprindo com suas obrigações fiscais." Acerca do contexto de surgimento do FATCA tais autores relatam que o objetivo com a legislação seria dificultar que os cidadãos americanos, aqueles que sejam residentes nos EUA, bem como empresas que sejam de propriedade de cidadãos americanos, chamados pela legislação de us persons praticassem atos de evasão fiscal foram dos EUA.

Ante essa necessidade de controle da riqueza é que surge o TIEA entre Brasil e EUA como o primeiro passo até a criação do FATCA no ano de 2010 como medida americana de controle de fluxo de riquezas envolvendo as informações que as instituições financeiras detenham em seu poder relacionadas aos que serão por ele abrangidos.

O FATCA, quando aplicado internamente, possui diversas implicações nas administrações públicas dos diversos países, consistindo na verdadeira aplicação prática do que se conhece como soft law ${ }^{10}$, ou seja, normas de direito internacional que possuem força cogente moderada e são frutos de encontros de âmbito mundial, podendo ser emanadas por organismos internacionais, possuindo força normativa tanto no direito privado quanto no âmbito do próprio direito internacional com aplicação menos cogente do que as leis internas, por exemplo.

A legislação do FATCA prevê, em síntese, a flexibilização de regras relacionadas ao sigilo de dados bancários que deverão ser remetidos pelas instituições financeiras brasileiras a administração tributária americana. Não se afasta aqui o fato de o FATCA representar violação, ainda que por via reflexa, do sigilo fiscal tendo em vista que remeter dados de operações financeiras pode demonstrar informações que repercutem diretamente na manifestação de riqueza tributável pela renda, por exemplo. Assim, essa visão de que o FATCA possui regras relacionadas ao sigilo bancário deve ser entendida com temperamentos posto que pode haver a violação de dados fiscais com a remessa de informações sobre operações financeiras.

Esse cenário mundial que motivou a criação da lei do FATCA e possui grande relevância para o Brasil nos evidencia uma imperiosa tendência de flexibilização de regras relacionadas tanto ao sigilo fiscal quanto o Bancário de modo a reduzir esse fluxo de valores sem que haja rastreamento ou qualquer medida de controle do destino, origem e destinatários dos recursos, o que contribui consideravelmente para a que a fiscalização tributária possa atuar e para que possa haver uma redução da evasão de divisas. 
Ponto importante acerca da celebração do tratado de concretização do FATCA pelo Brasil é que ele excepciona o que a nossa Constituição Federal tem como proteção ao sigilo fiscal e bancário, o que exige que as disposições constantes da legislação americana estejam de acordo com as prescrições de nossa ordem constitucional, devendo ser ressaltado que a celebração de tratados sobre troca de informações é caminho de extrema importância dentro do contexto mundial de combate ao crime organizado, lavagem de dinheiro, a própria corrupção, dentre outros. Em relação ao contexto jurídico interno para recepção do FATCA, o que ocorre é que a LC 105/01 prevê a flexibilização do sigilo bancário desde que tenha procedimento administrativo ou investigação em curso, o que já vem sendo questionado judicialmente por meio de diversas Ações Diretas de Inconstitucionalidade ${ }^{11}$ e recursos extraordinário junto ao STF.

O que deve ser entendido em relação ao FATCA ser incorporado pelo nosso sistema normativo, por meio de decreto, ainda em tramitação no Congresso Nacional ${ }^{12}$, mesmo sabendo da importância da aprovação para o combate ao crime organizado ou a lavagens de dinheiro no âmbito mundial, é que nosso sistema normativo não está pronto para medida de tal monta, tendo em vista que a legislação ${ }^{13}$ prevê que somente haverá a flexibilização desse sigilo com a existência de procedimento de investigação ou procedimento administrativo em andamento.

\footnotetext{
10 Não obstante as discussões acerco do que vem as ser o soft law, o que não é objeto de nosso estudo, o que é importante se entender é que essas normas de âmbito internacional podem ter força cogente dentro dos ordenamentos jurídicos a que se refiram, sempre observando o que cada sistema normativo entende como necessário para que as normas de âmbito internacional tenham força cogente.

11 Ações Diretas de Inconstitucionalidade ns 2.386, 2.397, 2.390 e 4.010.

${ }^{12}$ Cabe destacar que o texto do FATCA que será internalizado por meio de tratado celebrado entre Brasil e EUA está em tramitação junto ao Congresso Nacional por meio da MSC $\mathrm{n}^{\circ}$. 36/2015. Disponível em: http://www.camara.gov.br/proposicoesWeb/prop_ mostrarintegra?codteor=1300945\&filename=MSC+36/2015. Acesso em 10 de mai de 2015 .
} 
Dessa forma, é preciso que nossas leis estejam preparadas para recepção dessa postura internacional adotada pelo Brasil que não pode ser entendida de modo isolada apenas no âmbito internacional, em detrimento das leis internas e do que o sistema jurídico vigente prevê. A postura de combate ao crime organizado, a lavagem de dinheiro, a evasão de divisas, bem como a corrupção em si no âmbito internacional deve ser endossada pelo governo brasileiro, entretanto, o ordenamento jurídico interno deve ser preparado para tal desiderato. Por tudo que se vê, até o momento, o cenário que se desenha acerca da constitucionalidade do FATCA é que, de acordo com os termos da nossa legislação vigente, não há permissão para a troca automática das informações nos termos do que prevê a legislação americana como bem se pode observar na passagem elucidativa de ESTELYTA E BASTOS (2014, P. 21) constante abaixo:

A assinatura do IGA regulamentando o intercâmbio automático de informações de contribuintes brasileiros envolve o exame mais atento de questões constitucionais pendentes de pronunciamento pelo Supremo Tribunal Federal, especialmente sobre o sigilo de informações fiscais e a constitucionalidade da Lei Complementar 105/2001. Relembra-se que os governos de Brasil e EUA celebraram em 2007 um acordo internacional para a troca de informações em matéria tributária e o instrumento somente foi ratificado pelo Congresso brasileiro em 2013, por meio do Decreto 8.003/2013. Conquanto o acordo preveja o intercâmbio de informações tributárias entre os dois países, não há previsão para o método de intercâmbio automático de informações, o que faz com que o referido acordo não seja instrumento hábil para a adoção da política americana doForeign Account Tax Compliance Act (FATCA) pelas instituições brasileiras. Para tanto, seria necessária a concretização de um IGA para que as instituições financeiras e não-financeiras brasileiras pudessem adimplir à troca automática de informações. Esses acordos, não obrigatórios, foram concebidos como um meio de superar eventuais conflitos entre as legislações domésticas de cada país e aquelas suscitadas pela legislação do FATCA, bem como para padronizar sua implementação e reduzir os custos de compliance.

Cabe ressaltar que a internalização dos tratados por meio do correto procedimento utilizado para tanto, cria diploma normativo equivalente a lei ordinária o que pode encontrar o mesmo problema constitucional que já existe com a Lei Complementar $n^{\circ}$. 05/01 e pendente de manifestação no STF, frisando que não e pode criar uma exceção a proteção ao sigilo considerando constitucional sua quebra em relação a cidadãos americanos ou pessoas jurídicas de propriedade dessas pessoas. 


\section{PANORAMA JURÍDICO DO CONTROLE DE CONSTITUCIONALIDADE DA LEI $N^{\circ} .105 / 2001$}

A Lei Complementar $\mathrm{n}^{\circ}$. 105, de 2001 possui diversos questionamentos judiciais que são importantes para o correto entendimento do sigilo fiscal no país. Os dispositivos de tal diploma legal, especificamente os arts. $5^{\circ}$ e $6^{\circ}$, são questionados em diversas ações judiciais que buscam declarar a sua inconstitucionalidade, o que poderá refletir diretamente nas regras do sigilo dentro de nosso país. É importante se examinar como ocorre esse controle de constitucionalidade no país e qual será o impacto das decisões proferidas, levando em consideração que as regras questionadas tratam diretamente na questão do sigilo fiscal e bancário aqui discutidas.

\subsection{NOÇÕES GERAIS ACERCA DO CONTROLE DE CONSTITUCIONALIDADE NO BRASIL}

O controle de constitucionalidade no Brasil possui grande importância no que se refere à manutenção da ordem jurídica e à aplicação das disposições constitucionais tributárias, tendo em vista que grande parte das ações e recursos que chegam ao o Supremo Tribunal Federal (STF) referem-se a esse ramo do direito, seja pela agigantamento do arcabouço legislativo tributário, seja pela peculiaridade das discussões que envolvem a matéria, principalmente por se tratar de demandas que, em sua maioria, são pertinentes a direitos e garantias fundamentais dos contribuintes.

Todo o controle de constitucionalidade no Brasil recebeu forte influência do judicial review norte-americano e do modelo austríaco de controle de constitucionalidade. A maior característica do primeiro é o controle na forma difusa e diante do caso concreto das espécies de normas, ao passo que o segundo possui foco no controle concentrado e abstrato de disposições normativas, possuindo de forma mais impessoal. 
Esse controle misto adotado no Brasil passa pela ideia ou tem como pressuposto a rigide $^{14}$ da nossa Constituição Federal de 1988, ressaltando que o ordenamento normativo infralegal exige a realização de uma análise previa de recepção ou de revogação ${ }^{15}$, essa última relacionada às normas pré-constitucionais, para que depois seja realizada o controle dos dispositivos normativos que surjam.

Dessa forma tem-se que a rigidez constitucional, ao exigir procedimento diferenciado para a alteração do seu texto, demonstra que ela se encontra em grau de superioridade dentro do ordenamento jurídico, o que impõe seu respeito por todas as demais normas jurídicas, inclusive as próprias emendas à constituição. Basta que se observe o contraponto de ideias preconizado pelas constituições do tipo flexível, as quais podem ser alteradas por simples processo legislativo comum, sem maiores exigências.

Acerca das constituições flexíveis discorre CUNHA JR (2011, p.122) ${ }^{16}$ :

Já a constituição flexível é aquela que, em sentido oposto, pode ser alterada pelo mesmo procedimento observado paras as normas legais. A constituição não exige, para sua alteração, qualquer processo mais solene. Inexistem aqui as dificuldades apontadas para a reforma da Constituição rígida.

\subsection{MODELOS DE CONTROLE DE CONSTITUCIONALIDADE E OS EFEITOS DE SUAS DECISÕES}

O controle de constitucionalidade no Brasil possui uma classificação bem peculiar. Conforme já observamos, o Brasil possui um sistema misto de controle de constitucionalidade, podendo se dar de forma difusa - o qual é realizado por qualquer órgão do Poder Judiciário ou de forma concentrada - que é realizado por um órgão de cúpula, no caso, o STF.

\footnotetext{
${ }^{14}$ A doutrina aponta, divergindo dessa ideia, o controle de constitucionalidade de leis em face de constituição flexível em relação aos aspectos formais do diploma legal, mantendo-=se o entendimento de que não há como falar em controle sob aspectos materiais.

15 È mister destacar que as normas anteriores a promulgação da vigente Constituição Federal não sofrem controle de constitucionalidade face ao novo ordenamento jurídico. O quadro normativo anterior a uma nova constituição deve ser analisado sob o prisma do fenômeno da recepção ou da revogação da norma, e modo que o que se compatibiliza seja do ponto de vista forma, seja do ponto de vista material, com a nova ordem constitucional é recepcionado por ela, ao passo que o que vai de encontro ao ordenamento jurídico recém chegado é revogado.
} 
Os modelos de controle adotados no Brasil devem ser entendidos de acordo com o parâmetro utilizado para análise. Quanto ao parâmetro de controle, o Brasil adota toda a Constituição como norma de referencia, a ser confrontada com qualquer diploma que tenha constitucionalidade questionada. Os parâmetros de controle são os princípios constitucionais implícitos, os atos das disposições transitórias, ou seja, toda a Constituição do ponto de vista formal ${ }^{17}$ e material.

Quanto ao objeto de controle, relacionado aos atos sujeitos ao controle, a fiscalização acerca da constitucionalidade de atos normativos primários que tenham fundamento na própria constituição federal. Quanto ao momento, tem-se o controle repressivo que é representado pelo controle prévio do ato legislativo o qual não encontra utilização nem apoio na doutrina brasileira, ${ }^{18}$ há também o controle repressivo, adotado no Brasil, que é aquele que é utilizado após a vigência da norma.

Quanto a natureza do órgão com competência para o controle tem-se: controle político ou judicial, sendo este realizado por órgãos do poder judiciário ao passo que aquele é realizado por órgão alheio a tal poder, como ocorre na sanção presidencial e no controle de constitucionalidade no direito francês que é realizado através de uma corte constitucional, órgão alheio a estrutura do judiciário.

Quanto ao modo de manifestação, esse controle pode ser por via incidental, quando ocorre no curso de uma demanda já em andamento, por meio de exceção ou de defesa, ou pode ser por via principal, quando é o objeto primordial da demanda em curso, como ocorre por meio de ação direta. Pode ser ainda abstrato, ou em tese, quando a norma controlada é atacada num plano teórico e, finalmente, pode ser concreto quando a discussão ocorre diante de uma ação em andamento. ${ }^{19}$

\footnotetext{
${ }^{17}$ Há dois tipos de inconstitucionalidade que podem ser relacionados ao caso tratado no presente tópico, e que são referentes ao conteúdo da norma constitucional, ou seja, o controle sob a perspectiva material ou formal da norma constitucional. O primeiro, preconizado por Carl Schimidt em seu conceito de constituição política, refere-se à inconstitucionalidade $\mathrm{n}$ perspectiva material ou de conteúdo que seriam as normas tidas por essencialmente constitucionais. O segundo, que o mesmo Schimidit, denominou de leis constitucionais, refere-se a dispositivos de caráter formal, que estariam na Constituição e, por esse fato, independentemente do conteúdo, seriam constitucionais.

${ }^{18}$ Nesse ponto cabe destacar que o Supremo Tribunal Federal possui entendimento de que o controle preventivo apenas é admitido de forma concreta com a utilização de Mandado de segurança impetrado por parlamentar no intuito de defender propostas que violem o devido processo legislativo ou o a própria tramitação de projeto de lei (MS n. 24653 e 32033).

19 È importante esclarecer que o controle constitucional difuso é sempre incidental a uma demanda, mas nem sempre o controle incidental é difuso. Em alguns pauses pode haver o controle incidental concentrado como ocorre na Áustria e na Itália. Isso ocorre quando uma questão constitucional relacionada a uma demanda em andamento é submetida incidentalmente ao controle de uma corte constitucional, por exemplo. Não é difuso porque não é feito por órgãos diversos do judiciário, mas sim por um órgão especifico. (CUNHA JR, 2011, p. 315)
} 
O último modelo apresentado pela doutrina de CUNHA JUNIOR (2011) é quanto à finalidade do controle, podendo ser objetivo ou subjetivo. Este se refere ao exercício de defesa de um direito ou interesse subjetivo da parte, ao passo que aquele tem como destinação precípua a defesa objetiva da Constituição.

\subsection{O CONTROLE DE CONSTITUCIONALIDADE DA LEI COMPLEMENTAR No. 105, DE 2001}

A Lei Complementar $n^{\circ} .105$, de 2001 surgiu cercada de controvérsias sobre a sua constitucionalidade, especialmente quanto ao disposto nos artigos $5^{\circ}$ e $6^{\circ}$, sobretudo, no ponto que determina que as instituições financeiras prestem informações acerca das operações que enumera e realizadas por seus clientes à administração tributária da União.

O ponto central da controvérsia refere-se ao cotejo de tais dispositivos com a proteção ao sigilo bancário e com os demais dispositivos que tratam da privacidade dos cidadãos, bem como a relação de tais pontos com a troca de informações no âmbito internacional. De um lado, há os que apontam a inconstitucionalidade da norma, ao passo que outros veem tais dispositivos em perfeita harmonia com o ordenamento constitucional, com os acordos e tratados acerca de troca de informações, bem como com a demonstração de transparência muito difundida no cenário mundial atualmente.

Cabe ressaltar que há igual discussão quanto à validade do Decreto nº 3724 , de 2001 que "regulamenta o art. $6^{o}$ da Lei Complementar $n^{o}$ 105, de 10 de janeiro de 2001, relativamente à requisição, acesso e uso, pela Secretaria da Receita Federal, de informações referentes a operações e serviços das instituições financeiras e das entidades a elas equiparadas", principalmente que eventual declaração de inconstitucionalidade da lei esvazia o objeto do decreto.

\footnotetext{
20 No recurso foi questionada a utilização de informações bancárias pela Recita Federal do Brasil obtidas junto às instituições financeiras, para instauração e instrução de processo administrativo fiscal.
} 
O questionamento da constitucionalidade dos dispositivos da Lei Complementar $\mathrm{n}^{\circ} 105$, de 2001 se dá tanto no âmbito do controle incidental quanto no concentrado. ${ }^{20}$ No controle incidental, há decisão proferida no RE nº $389.808 \mathrm{PR}^{21}$, (Recurso Extraordinário com embargos de declaração pendentes de julgamento), de relatoria do Ministro Marco Aurélio no sentido da inconstitucionalidade da lei, com interpretação conforme a Constituição.

Nessa decisão foram fixadas as seguintes premissas, nos termos do julgamento divulgado no informativo de jurisprudência $\mathrm{n}^{\circ} .613$ :

\section{PONTOS CONTRÁRIOS A QUEBRA DO SIGILO}

a) Assegurar a privacidade das correspondências, das comunicações telegráficas, de dados e telefônicas, sendo possível a mitigação por ordem judicial, para fins de investigação criminal ou de instrução processual penal;

b) Resguardar o cidadão de atos extravagantes que possam, de alguma forma, alcançá- lo na dignidade, de modo que o afastamento do sigilo apenas seria permitido mediante ato de órgão eqüidistante (Estado-juiz).

c) Observância da supremacia da Constituição, tendo em conta que ato normativo abstrato autônomo haveria de respeitar o que nela contém, o que mostra que a lei teria extrapolado as normas constitucionais;

d) Primado do Judiciário, porquanto não se poderia transferir a sua atuação, reservada com exclusividade por cláusula constitucional, a outros órgãos, sejam da Administração federal, estadual ou municipal;

e) Prerrogativa de foro, haja vista que seu detentor somente poderia ter o sigilo afastado ante a atuação fundamentada do órgão judiciário competente.

f) A decretação da quebra do sigilo bancário não poderia converter-se em instrumento de indiscriminada e ordinária devassa da vida financeira das pessoas em geral e que inexistiria embaraço resultante do controle judicial prévio de tais pedidos.

\footnotetext{
21 SIGILO DE DADOS - AFASTAMENTO. Conforme disposto no inciso XII do artigo $5^{\circ}$ da Constituição Federal, a regra é a privacidade quanto à correspondência, às comunicações telegráficas, aos dados e às comunicações, ficando a exceção - a quebra do sigilo submetida ao crivo de órgão equidistante - o Judiciário - e, mesmo assim, para efeito de investigação criminal ou instrução processual penal. SIGILO DE DADOS BANCÁRIOS - RECEITA FEDERAL. Conflita com a Carta da República norma legal atribuindo à Receita Federal - parte na relação jurídico-tributária - o afastamento do sigilo de dados relativos ao contribuinte. (RE 389808, Relator(a): Min. MARCO AURÉLIO, Tribunal Pleno, julgado em 15/12/2010, DJe-086 DIVULG

09-05-2011 PUBLIC 10-05-2011 EMENT VOL-02518-01 PP-00218 RTJ VOL-00220- PP-00540)
} 
Concluindo o julgamento, o Ministro Marco Aurélio, relator, conferiu à legislação de regência interpretação conforme a Constituição, tendo como conflitante com esta qualquer interpretação que implique afastamento do sigilo bancário do cidadão, pessoa natural ou jurídica, sem ordem emanada do Judiciário.

\section{PONTOS FAVORÁVEIS À QUEBRA DO SIGILO}

a) Não se trataria de quebra de sigilo ou da privacidade, mas sim de transferência de dados sigilosos de um órgão, que tem o dever de sigilo, para outro, o qual deverá manter essa mesma obrigação, sob pena de responsabilização na hipótese de eventual divulgação desses dados.

b) Se a Receita Federal teria acesso à declaração do patrimônio total de bens dos contribuintes, conjunto maior, qual seria a razão de negá-lo quanto à atividade econômica, à movimentação bancária, que seria um conjunto menor.

c) $\mathrm{O}$ acesso aos dados estaria respaldado no artigo o no art. $145, \S 1^{\circ}$, da $\mathrm{CF}^{22}$ que a lei que normatizara a aludida transferência respeitaria os direitos e garantias fundamentais.

No âmbito do controle concentrado, observa-se a existência de cinco ações diretas de inconstitucionalidade em tramite no Supremo Tribunal Federal, conforme resumo abaixo:

a) $\mathrm{ADI} \mathrm{n}^{\circ} 4040$, ajuizada em 25/01/2008, que tem como Autor o Conselho Federal da Ordem dos Advogados do Brasil, cujo objeto é o art. $5^{\circ}$ da LC 105/01 e o parâmetro de controle são os incisos X, XII e LV do art. $5^{\circ}$ da Constituição Federal;

b) $\mathrm{ADI} \mathrm{n}^{\text {o. }} 2859$ ajuizada em 20/03/2003 que tem como Autor o Partido Trabalhista Brasileiro cujo objeto é o art. $5^{\circ}$ da Lei Complementar $\mathrm{n}^{\circ} 105$, de 2001, o Decreto $n^{\circ} 4489$, de 2002, Decreto $n^{\circ} 4545$, de 2002, tendo como o parâmetro de controle: os artigos $2^{\circ}$ e $5^{\circ}$, caput, e incisos II, X, XII, LIV, LV, LVI; art. 48, XIII; artigo 84, IV; art. 192, caput, todos da Constituição Federal vigente.

\footnotetext{
${ }^{22}$ Art. $145 \ldots \S 1^{\circ}(\ldots)$ facultado à administração tributária, especialmente para conferir efetividade a esses objetivos, identificar, respeitados os direitos individuais e nos termos da lei, o patrimônio, os rendimentos e as atividades econômicas do contribuinte.
} 
c) ADI no 2397, ajuizada em 29/01/2001, que tem como Autora a Confederação Nacional da Indústria, cujo objeto são: artigos $3^{\circ}, \S 3^{\circ}$; art. $5^{\circ}$ e art. $6^{\circ}$ (pedido de interpretação conforme, para retirar a possibilidade de requisição das informações pela autoridade administrativa), todos da Lei Complementar $n^{\circ} 105$, de 2001; Decreto $\mathrm{n}^{\circ}$ 3724, de 2001, que regulamenta o art. $6^{\circ}$ Lei Complementar $n^{\circ} 105$, de 2001; art. $1^{\circ}$ da Lei Complementar $n^{\circ} 104$, de 2001, que altera o Código Tributário Nacional. O parâmetro de controle são os incisos X, XII, XXV do art. $5^{\circ}$ e $\S 1^{\circ}$ do art. 145, todos da Constituição Federal;

d) $\mathrm{ADI} \mathrm{n}^{\mathrm{o}} 2390$ ajuizada em 15/01/2001, que tem como Autor o Partido Social Liberal, cujo objeto são os arts. 5 e $6^{\circ}$ da Lei Complementar $n^{\circ} 105$, de 2001e o Decreto $\mathrm{n}^{\circ}$. 3724, de 2001, tendo como o parâmetro de controle são o artigo $5^{\circ}$, caput e incisos, X, XII, LIV, da Constituição Federal vigente;

e) ADI $\mathrm{n}^{\mathrm{o}}$ 2386, ajuizada em 12/01/2001, que tem como Autor a Confederação Nacional do Comércio, cujo objeto são os arts. $5^{\circ}$ e $6^{\circ}$ da Lei Complementar $n^{\circ}$ 105, de 2001, tendo como parâmetro de controle o artigo $5^{\circ}$, caput e incisos X e XXV, da Constituição Federal vigente.

Conforme se percebe, as Ações Diretas de Inconstitucionalidade indicadas são referentes aos artigos $5^{\circ}$ e $6^{\circ}$ da Lei Complementar $n^{\circ} 105$, de 2001, bem como às alterações realizadas no Código tributário Nacional pela Lei Complementar $\mathrm{n}^{\circ} 104$, de 2001, tendo como principal questionamento a possibilidade de instrução de processos administrativos fiscais mediante informações obtidas junto às diversas instituições financeiras do país.

Os argumentos contrários à constitucionalidade da lei em comento são, basicamente, a violação ao sigilo bancário, à intimidade e à privacidade das pessoas, ao devido processo legal e ao contraditório e à ampla defesa na obtenção de dados sem manifestação do contribuinte, tendo como ponto importante o fato de que a quebra de sigilo bancário pela Administração Tributária submeter-se-ia à reserva de jurisdição, apenas sendo possível mediante autorização judicial, ou mesmo de órgão com poderes jurisdicionais, como, as comissões parlamentares de inquéritos.

A ideia central das Ações Diretas é a violação a direitos e garantias fundamentais dos contribuintes que teriam a exposição de seus dados bancários tida como regra, sem que lhes fosse dado o direito de manifestação, ficando tais informações passíveis de acesso a qualquer tempo e a qualquer hora. Alega-se nesse ponto, que os contribuintes que em situação regular e 
aqueles em procedimento de investigação ou fiscalização estariam numa mesma situação, o que implicaria ainda violação à isonomia.

A divergência sobre a utilização de sigilo de dados bancários para realização da fiscalização tributária ou mesmo para a instrução de procedimentos administrativos fiscais ganha importante relevo diante dos pontos delineados nas AdIns mencionadas, posto que já há decisão em sede de recurso extraordinário, conforme mencionado, no sentido da inconstitucionalidade.

A decisão favorável aos contribuintes proferida no $\mathrm{RE} \mathrm{n}^{\circ}$. $389.908 \mathrm{PR}$ foi proferida em sede de controle difuso, cujos efeitos da decisão são inter partes, não havendo obrigatoriedade de ser seguida pelos diversos tribunais do país. Assim, tem-se um precedente favorável ao contribuinte que ainda pode ser revertido por ocasião do julgamento das ações diretas mencionadas. ${ }^{23}$

Esse cenário jurídico-tributário possui grande relevância para o Brasil no que se refere à sua posição no cenário internacional, tendo em vista que as regras sobre os sigilos sobre operações bancárias perante a fiscalização tributária são levadas em conta para que haja a classificação de um país como paraíso fiscal ou como ente com regime jurídico favorecido.

\subsection{A TROCA DE INFORMAÇÕES SIGILOSAS ENTRE AS ADMINISTRAÇÕES TRIBUTÁRIAS E A LEI COMPLEMENTAR No 105, DE 2001}

Prática muito difundida entre as diversas Administrações mundo agora é troca de informações, principalmente, quando se realiza seu confronto com as regras de proteção ao sigilo bancário. O Código Tributário Nacional trata da troca e da obtenção de informações, especificamente nos artigos de 197 a 199 os quais são analisados por PAULSEN (2013, p.1259) ${ }^{24}$.

\footnotetext{
23 Informação curiosa a ser prestada e que pode auxiliar no entendimento do julgamento das cinco ações diretas mencionadas é que toda são de relatoria do Ministro Antônio Dias Tóffoli, o qual se manifestou pela constitucionalidade da Lei Complementar $\mathrm{n}^{\mathrm{o}} 105$, de 2001 , no julgamento do $\operatorname{REn}^{\circ}$. 389.908 .
} 
$\mathrm{Na}$ quase totalidade dos países ocidentais, existe a possibilidade de acesso às movimentações bancárias sempre que tal seja importante para apuração de crimes e fraudes tributárias em geral. Dos 30 países integrantes da Organization for Economic Coperation and Development (de que são parte Alemanha, Reino Unido, Estados Unidos, Austrália, Itália e Japão e a Suíça inclusive, dentre outros), apenas dois (República Eslovaca e Luxemburgo) não facultavam tal aceso, conforme artigo do Ministro Jose delgado publicado na RE $n^{\circ}$. 22, nov-dez/01. Via de regra, o acesso aos dados depende de ordem judicial à vista de indícios de irregularidade

A troca de informações no intuito de otimização da atividade de fiscalização possui precedente desde a Lei $\mathrm{n}^{\circ}$. 8021/1990, passando pela Lei $\mathrm{n}^{\circ}$. 9311/96, a qual institui a Contribuição Provisória sobre Movimentação ou Transmissão de Valores e de Créditos e Direitos de Natureza Financeira (CPMF), implementou o fornecimento de informações pelos Banco acerca de operações feitas por clientes, a Lei $n^{\circ} 10.174$, de 2001, a Lei Complementar $n^{\circ}$ 104, de 2001 que alterou os artigos supracitados do CTN, e, enfim, a Lei Complementar $\mathrm{n}^{\circ} 105$, de 2001,objeto de grande controvérsia judicial.

Segundo a Organização Mundial do Comércio $(\mathrm{OCDE})^{25}$, foi desenvolvido o chamado Global Forum on Transparency and Exchange of Information for Tax Purposes, através de trabalhos que se iniciaram no ano de 2000 cujo objetivo era buscar o cumprimento de obrigações tributárias com foco direcionado aos paraísos fiscais. Ele foi composto, inicialmente, por membros da OCDE que convergiam pelo estabelecimento de regras de transparência no que se refere, especificamente, à troca de informações relacionadas a matéria tributária, tendo sido reestruturado no ano de 2009 com composição atual de 126 membros .

O Global Forum realiza reuniões ${ }^{26}$ anuais que produzem relatórios que nortearam os países a como proceder e quais as tendências a serem utilizadas no que se refere a troca de informações, produzindo demonstrativos de resultados nos quais se verifica tanto as medidas a serem adotadas como as tendências acerca dessa troca de informações. Do ultimo relatório da OCDE, produzido em Berlin no ano de 2014, extrai-se as seguintes diretrizes que norteiam a elevação do nível de transparência que se adotará no mundo:

\footnotetext{
${ }^{25}$ Organização Mundial do Comércio . Global Forum on Transparency and Exchange of Information for Tax Purposes. Disponível em: http://www.oecd.org/tax/transparency/. Acesso em 10/04/2015.

${ }^{26}$ Cabe destacar que diversas reuniões anuais são feitas no âmbito do Global Fórum, tendo destaque a que ocorreu em outubro de 2014 na cidade de Berlin na qual contou com a participação de mais de 300 representantes de 101 países, bem como diversos organismos internacionais
} 


\begin{abstract}
the commitments by an overwhelming majority of Global Forum members to implement the new standard on Automatic Exchange of Information (AEOI) by 2017 or by end 2018 accompanied by an expression of support for its members, in particular developing countries, to participate in the new, transparent EOI environment;The major outcome of the meeting was the resolve of Global Forum members to take tax transparency to a new level. This is evidenced by the following: the commitments by an overwhelming majority of Global Forum members to implement the new standard on Automatic Exchange of Information (AEOI) by 2017 or by end 2018 accompanied by an expression of support for its members, in particular developing countries, to participate in the new, transparent EOI environment; the adoption, in principle, of revisions to the Terms of Reference, which will now include a requirement to maintain beneficial ownership information, to ensure that the standard on exchange of information on request continues to reflect the evolution of the dynamic EOI environment; the changes will be applicable to the next round of reviews for EOI on request (starting in 2016);
\end{abstract}

A utilização de mecanismos de transparência e troca de informações recebe tratamento prioritário pelos organismos internacionais quando se trata de combate à lavagem de dinheiro, ao crime organizado e ao planejamento tributário internacional abusivo, levandose em conta que é ,a partir da legislação interna, que se define como o país atuará no âmbito internacional nessa seara.

\title{
5. OS PARAÍSOS FISCAIS E OS PAÍSES COM REgIME TRIBUTÁRIO FAVORECIDO
}

O tema aqui proposto pressupõe que se tenha também em conta como se caracterizam os paraísos fiscais no contexto jurídico mundial. Neste tópico, será tratada a a concepção de paraíso fiscal, de modo que se absorva a diferença entre o que seria paraíso fiscal e o que seria país com regime tributário favorecido. Essa diferença possui diversas implicações internacionais.

\subsection{NOÇÕES GERAIS SOBRE PARAÍSOS FISCAIS E A CARACTERIZAÇÃO DOS PAÍSES COM TRIBUTAÇÃO FAVORECIDA}

PINTO (2007) afirma que:

O conceito de paraísos fiscais, como hoje é conhecido, passou a ser mais amplamente utilizado a partir do século XX. Contudo já na Grécia antiga os mercadores estocavam seus produtos nas ilhas próximas a Atenas visando o não pagamento de $2 \%$ sobre a importação e a exportação. Nos séculos XVI e XVII, um mínimo tributos, tarifas e restrições alfandegárias era aplicado nos portos de Flanderes, em comparação a outros portos da época.Outra referencia importante é que a Jamaica, em 1989, oferecia aos clientes do canadense Bank of New Scotia diversas vantagens financeiras e tributárias diferenciadas. 
Ainda na doutrina do citado autor, observa-se que não há uma definição clara e especifica para o que se conhece como paraísos fiscais, pois, para ele:

\section{(...)}

podem ser considerados aqueles ordenamentos que isentam operações normalmente tributadas de acordo com os princípios gerais comumente aceitos ou tributam a taxas anormalmente baixas, procurando seduzir investidores estrangeiros, limitando-se a cobrar uma taxa fiscal anual para o registro da empresa, ou, em alguns casos, um pequeno imposto adicional sobre o valor do capital, registrado.

(...)

MASON (2010, p. 143), por sua vez, resume a evolução da legislação nacional sobre os paraísos fiscais:

No direito brasileiro, o primeiro diploma legal a tratar de paraísos fiscais foi a Lei Federal $n^{\circ} 9.4320$ de 27 de dezembro de 1996.31 Foi a primeira vez que a lei nacional tratou de questões como preços de transferência, pessoa vinculada e denominação legal de paraísos fiscais. O caput da lei acima mencionada define paraíso fiscal como tributação da renda inexistente ou em alíquota máxima igual ou inferior a vinte por cento. Posteriormente, o art. $8^{\circ}$ da Lei $n^{\circ} 9.779$, de 19 de janeiro de 199, determinou que os rendimentos decorrentes de qualquer operação, em que o beneficiário seja residente ou domiciliado em país que não tribute a renda ou que a tribute a alíquota máxima inferior a 20\%, sujeitam-se à incidência do Imposto de Renda na fonte à alíquota de $25 \%$, ressalvando-se os seguintes casos: remessas para pagamentos de arrendamento mercantil; de juros em empréstimos acima de 15 anos; de países que têm tratado para evitar dupla tributação com o Brasil; de juros ou comissões para colocação de títulos brasileiros no exterior com prazo de amortização de 96 meses; de juros de desconto, no exterior, de cambiais de exportação e as comissões de banqueiros inerentes a essas cambiais; de juros e comissões relativos a créditos obtidos no exterior e destinados ao financiamento de exportações do Brasil.

A Lei $n^{\circ}$ 9430/96 é o diploma que regula o assunto no ordenamento jurídico pátrio, entretanto, ela não apresenta definição precisa de quais as regras para o enquadramento de um ente soberano como paraíso fiscal ou como um país com tributação favorecida. Não obstante essa ausência, a Lei apresenta parâmetros o que ela denomina de regime fiscal privilegiado.

Segundo o contido no art. 24-A, parágrafo único, da Lei, para que um país não seja enquadrado como de regime fiscal privilegiado é imprescindível que ele:

I - não tribute a renda ou a tribute à alíquota máxima inferior a $20 \%$ (vinte por cento); II - conceda vantagem de natureza fiscal a pessoa física ou jurídica nãoresidente: a) sem exigência de realização de atividade econômica substantiva no país ou dependência; b) condicionada ao não exercício de atividade econômica substantiva no país ou dependência; III - não tribute, ou o faça em alíquota máxima inferior a $20 \%$ (vinte por cento), os rendimentos auferidos fora de seu território; IV - não permita o acesso a informações relativas à composição societária, titularidade de bens ou direitos ou às operações econômicas realizadas.

Tais regras são encontradas nos estudos e recomendações da OCDE, conhecido como "Harmful Tax Competition, An Emerging Global Issue",27. Esse documento é um relatório sobre as regras que permitem identificar paraísos fiscais, abrigando, no seu Capítulo 2, 
os preceitos que permitem distinguir entre "paraísos fiscais" e o que denomina de "regimes fiscais preferenciais".Apresenta também características que possibilitam a atração de investimento estrangeiro, bem como as linhas norteadoras que ajudarão os Governos a identificar paraísos fiscais e os distinguir dos regimes fiscais preferenciais positivos e negativos, caracterizando, dentre esses últimos, aqueles que podem ser causadores de concorrência fiscal prejudicial ${ }^{28}$.

O Relatório da OCDE apresenta os seguintes fatores para identificar os paraísos fiscais $^{29}$ bem resumidos por BIANCO (2007, p. 45):

a quase ausência de tributação sobre a renda auferida e sobre capital investido; a garantia legal de manutenção das atividades do investidor em absoluto segredo; a ausência de mecanismos institucionais que permitam a troca de informações fiscais com as autoridades governamentais de outros países; a falta de uma legislação que vede a constituição apenas formal de pessoas jurídicas, sem uma efetiva atividade empresarial;

Tal relatório atribui grande relevância, para caracterização dos paraísos fiscais, às ações tendentes a troca de informações, especificamente no que se refere aos " tratados de assistência mútua em matérias criminais e relacionados com determinado tipo de crimes, tais como o narcotráfico, ou a troca de informações em casos de indícios fundados de crime de fraude fiscal".

27 At the outset, a distinction must be made between three broad categories of situations in which the tax levied in one country on income from geographically mobile activities, such as financial and other service activities, is lower than the tax that would be levied on the same income in another country:

i) the first country is a tax haven and, as such, generally imposes no or only nominal tax on that income; ii) the first country collects significant revenues from tax imposed on income at the individual or corporate level but its tax system has preferential features that allow the relevant income to be subject to low or no taxation;

28 While the concept of "tax haven" does not have a precise technical meaning, it is recognised that a useful distinction may be made between, on the one hand, countries that are able to finance their public services with no or nominal income taxes and that offer themselves as places to be used by non-residents to escape tax in their country of residence and, on the other hand, countries which raise significant revenues from their income tax but whose tax system has features constituting harmful tax competition.

29 itself, as a place to be used by non-residents to escape tax in their country of residence. Other key factors which can confirm the existence of a tax haven and which are referred to in Box I are: $(b)$ laws or administrative practices which prevent the effective exchange of relevant nformation with other governments on taxpayers benefiting from the low or no tax jurisdiction; $(c)$ lack of transparency and $(d)$ the absence of a requirement that the activity be substantial, since it would suggest that a jurisdiction may be attempting to attract investment or transactions that are purely tax driven (transactions may be booked there without the requirement of adding value so that there is little real activity, i.e. these jurisdictions are essentially "booking centres"). 
Quanto aos regimes fiscais preferenciais ou entes fiscais com tributação favorecida o Relatório da OCDE aponta diversos elementos que os caracterizam:

a) nível de tributação ou taxas efetivamente baixa; b) adoção pelo país de medidas que excluem os residentes de determinados benefícios fiscais, de modo a atrair maiores investimentos para o país; c) falta de transparência na concessão de vantagens oferecidas, através de regulamentação negociável caso a caso, o que prejudica eventuais medidas defensivas adotadas por outros países; c) Adoção pelo Estado de políticas discriminatórias, conhecidas como "ring-fenced regime"; d) falta de troca de informações efetivas fomentadas pela dificuldade ou limitação de acesso às informações bancárias;

O relatório ainda indica outros fatores que, apesar de não serem considerados como sendo fatores - chaves para identificação dos regimes fiscais preferenciais prejudiciais, podem caracterizar tal situação, quais sejam:

a) a definição de forma artificial da base tributável; b)a falha na implementação dos princípios internacionais sobre preços de transferência; c) a captação de rendimento de fonte estrangeira no pais de residência, de maneira a fomentar a utilização de treaty shopping; d) alíquotas de impostos maleáveis ou flexibilização na própria base tributável; e) existência de disposições sobre sigilo: dificuldade de acesso à informação bancária ou a existência de instrumentos financeiros com garantia de anonimato; f) acesso a uma vasta rede de tratados em matéria fiscal; g) regimes tributários que permitam a utilização de manobras tendentes à redução do pagamento de tributos; h) permissão ou incentivo a prática de operações meramente formais, as quais não seriam caracterizadas substancialmente;

Destarte, observa-se que os paraísos fiscais e os países com tributação favorecida ou regime fiscal privilegiado possuem uma relação que pode ser entendida como de gênero e espécie. Pode ser compreendido como gênero que envolve entes soberanos que, não possuem tributação diferenciada ou inexistente, mas também possuem qualquer regra que forneça a ideia de que as relações tributárias nas operações nele desenvolvidas são sujeitas à menor fiscalização ou mesmo protegidas pelo sigilo fiscal, empresarial e até bancário.

Já os países com tributação favorecida, são espécie de países nos quais a característica predominante é a reduzida carga tributária, seja por meio de alíquotas baixas ou mesmo por meio de bases de cálculo inexistentes. A ideia de países com regime jurídico privilegiado leva em conta, para sua definição, aspectos mais específicos que demonstram a existência de uma espécie de regime fiscal diferente, tendo como base a impossibilidade de 
troca de informação fiscal e bancária, a ausência de controle empresarial ou sobre operações societárias e fiscais, etc.

Assim, tem-se que a noção de paraísos fiscais engloba a noção de países com tributação favorecida, ao passo que este se refere a regime de tributação menos gravosa ou menos onerosa, e aquele refere-se a outros aspectos, além da menor carga tributária, como sigilo fiscal, sigilo bancário, ausência de transparência nas operações em seu território, etc.

O Relatório da OCDE apresenta a importância dessa distinção, reforçando a ideia de que suas recomendações são utilizadas de acordo com a existência de um paraíso fiscal ou de um ente com tributação favorecida:

In the first case, the country has no interest in trying to curb the "race to the bottom" with respect to income tax and is actively contributing to the erosion of income tax revenues in other countries. For that reason, these countries are unlikely to co-operate in curbing harmful tax competition. By contrast, in the second case, a country may have a significant amount of revenues which are at risk from the spread of harmful tax competition and it is therefore more likely to agree on concerted action. 44. Because of this difference, this Report distinguishes between jurisdictions in the first category, which are referred to as tax havens, and jurisdictions in the second category, which are considered as countries which have potentially harmful preferential tax regimes. This distinction is particularly relevant for the application of the Recommendations in Chapter 3 since, for example, Recommendation 16 applies only to tax havens, whereas the Guidelines apply only to harmful preferential tax regimes. The following sections II and III present the factors to be used to identify each category.

\subsection{A RELEVÂNCIA DA TROCA DE INFORMAÇÕES E SUA RELAÇÃO COM OS ENTES COM REGIME TRIBUTÁRIO ESPECIAL}

Ponto imprescindível para o entendimento do tema aqui prposta é o entendimento de que as restrições à troca de dados sigilosos é um fator decisivo para a identificação dos paraísos fiscais, pois o que se compreende é que uma limitação de acesso às informações sobre determinadas operações impede a existência de uma efetiva e ampla fiscalização e aplicação das leis fiscais, cabendo sempre uma ponderação entre os contribuintes, de modo que se respeite a isonomia em sua perspectiva material.

BIANCO (2007) afirma que o relatório da OCDE visto acima tem como objetivo principal a criação de uma política de combate às distorções geradas pela concorrência fiscal danosa adotada por alguns países, que gera distorções nas decisões dos investidores e de financiamento dos agentes econômicos . Em passagem elucidativa esclarece que:

O que a OCDE procurou evidenciar, em seu relatório, é que existem práticas extremadas que são adotadas por alguns países que fogem dos padrões de 
normalidade e usualidade geralmente praticados, e que trazem prejuízos aos demais países. Daí serem caracterizados como práticas concorrenciais danosas.

Cada país adota as regras que visam a evitar esse abuso na utilização de empresas off shore, não havendo um regime uniforme em todo o mundo acerca de tal ponto. O que deve ser observado por cada nação foi definido pelo relatório da OCDE sob três perspectivas: medidas de caráter coletivo, medidas de caráter interno e medidas relacionadas aos tratados de dupla tributação.

BIANCO (2007, p. 139) bem resume tais medias narrando que:

As medidas de caráter coletivo sugeridas pela OCDE são basicamente: a troca de experiências entre os países membros e não membros, visando ao combate a competição fiscal danosa; criação de uma lista negra de paraísos fiscais e a instituição de regimes tributários restritivos e rigorosos com os contribuintes que desenvolvam operações envolvendo esses países; a elaboração de uma lista de princípios de uma boa administração fiscal como se fossem critérios mínimos a serem obedecidos, sob pena de ser caracterizada a competição fiscal danosa. No que diz respeito as tratados contra a dupla tributação, as sugestões são no sentido de intensificar a troca de informações sobre os contribuintes com operações envolvendo regimes fiscais favorecidos; a inclusão nos tratados de dispositivos vedando o gozo de benefícios fiscais quando os contribuintes possam estar se beneficiando de medidas que constituam concorrência fiscal danosa; e a previsão de realização de procedimentos de fiscalização conjuntos, levados a efeito simultaneamente pelos países envolvidos nas operações internacionais desenvolvidas pelos contribuintes;

Nessa mesma sequência de aspectos de controle e transparência, faz-se necessário ter a noção do conceito dede Controlled Foreing Companies (CFC) que, na visão de BIANCO (2007, p. 110):

Trata-se de um regime especial de tributação, que no exterior é aplicável em situações excepcionais, quando presentes algumas condições envolvendo países com tributação favorecida. O importante porém, é demonstrar que o regime especial CFCs se insere num contexto de esforço internacional com vistas a combater chamada concorrência fiscal danosa, praticada por paraísos fiscais e por países com regimes tributários favorecidos.

As chamadas CFCs não consistem em um regime geral de tributação da renda em bases universais, mas em normas especiais, que visam a evitar que, pela interposição de sociedade, o contribuinte possa afastar ou diferir o pagamento do imposto de renda sobre rendimentos por ele auferidos no exterior. São considerados como normas antiabusivas, que só se aplicam em circunstancias excepcionais, quando presentes determinadas condições, são conhecidas como regime especial de transparência fiscal. 
Continuando a sequência de demonstração de elementos que evidenciam a necessidade de adoção de instrumentos de transparência, observa-se o disposto no que está sendo chamado de padrão internacional de acesso à informação (internationally agreed standard, ). No âmbito do Fórum Global da Transparência e Troca de Informações para Fins Tributários ${ }^{30}$, chegando- se à ideia de que não há possibilidade de manutenção de sigilo bancário em face do fisco, conforme explicita VALADÃO (2013, p. 33):

(...)

Em função da atuação do Fórum Global, o cenário mudou bastante nos últimos cinco anos. Ocorreu que as grandes empresas e o grande capital se internacionalizaram e apenas os dados internos dos países não são mais suficientes para se verificar as bases tributáveis das pessoas físicas e jurídicas, daí a necessidade de intercâmbio de informações entre os fiscos dos diversos países. O padrão mínimo do Fórum Global implica a existência de pelo menos doze acordos internacionais, sem oposição de sigilo bancário ao fisco, dentre outras medidas de transparência, como a proibição de títulos e ações ao portador.

Acerca da posição do Brasil nessa nova fase, observa VALADÃO (2013):

(..)

O Brasil passou recentemente pela revisão de seus procedimentos frente ao Fórum Global, a qual tem duas fases. ${ }^{31}$ A primeira fase refere-se à estrutura legal e a segunda à efetividade da transparência e troca de informações. Ambas as fases já terminaram (a $1^{\mathrm{a}}$ foi concluída em janeiro de 2012 e a $2^{\mathrm{a}}$ em maio de 2013), e o Brasil não teve maiores problemas, tendo sido considerado no relatório que o fisco brasileiro tem acesso às informações bancárias, sem prévia autorização judicial (a LC 105/2001 está sub judice, mas é válida). Pois bem, uma das recomendações que o Brasil teve refere- se à impossibilidade de acesso direto às informações bancárias sem antes ter que intimar o contribuinte a fornecê-la, e a impossibilidade de exceções a esta regra (ainda que haja o recurso judicial que possa contornar esta condição). Isto porque, em certas situações, a comunicação ao contribuinte de que $\mathrm{o}$ fisco está em busca de suas informações bancárias pode interferir e mesmo atrapalhar um resultado eficiente da auditoria. Esta possibilidade faz parte do padrão internacional atual.

30 O Fórum Global sobre Transparência e Troca de informações para fins fiscais é a estrutura multilateral que possui atividade ampla sendo composta por mais de 90 países que desenvolvem suas atividades sem exigência de discriminação. O Fórum Global tem atuação no monitoramento acerca da aplicação ou utilização de normas relacionadas a troca de informações para efeitos fiscais, ressaltando que um dos pilares dessa atuação são as normas que prevêem o intercâmbio internacional de pedidos de trocas de informação a qual será de grande relevância para a administração, com a observância da aplicação das leis tributárias internas de um ente soberano. 


\section{CONSIDERAÇÕES FINAIS}

Como se percebe, o atual cenário mundial, no que se refere à troca de informações entre as instituições bancárias e o fisco, tem grande relevância na caracterização de entes soberanos como regimes tributários especiais, o que nos evidencia a necessidade de uma nova leitura dos institutos do sigilo fiscal, bancário, especificamente, quando relacionados à troca de informações entre o fisco e instituições financeiras.

Todos os instrumentos internacionais que tratam da troca de informações entre as instituições financeiras e o Fisco adotam a regra de que a transparência de informações bancárias é premissa de uma administração tributária eficiente e uma adequada aplicação da legislação interna, o que torna um país dentro de padrões aceitos internacionalmente no tocante à gestão de tributos.

No Brasil, esse cenário está regulado pela Lei Complementar nº 105 , de 2001, a tem sua constitucionalidade questionada no Supremo Tribunal Federal, tendo em vista que, no ordenamento jurídico brasileiro, a liberdade de acesso a dados bancários pelo Fisco, como forma de fiscalização tributária, encontra obstáculo nos direitos e garantias fundamentais dos contribuintes, especificamente, na proteção a intimidade, vida privada, isonomia ou mesmo na dignidade da pessoa humana, o que torna peculiar a posição do Brasil nesse tema.

Esse cenário jurídico constitucional pode o Brasil há um posicionamento peculiar no âmbito internacional, podendo estar de acordo com o que a OCDE preconiza sobre a transparência nas operações sujeitas a tributação ou manter sua posição de proteger o contribuinte na perspectiva do sigilo fiscal e bancário, na sua posição tradicional de de que as operações bancárias apenas possam ser evidenciadas a parir de comando jurisdicional.

É muito importante que o cenário internacional seja observado quando da decisão, entretanto, nossa Suprema Corte não pode tomar suaa decisão baseada apenas no que os organismos internacionais e demais entes desenvolvidos utilizam como prática. A realidade sócio-cultural de nosso país exige uma ponderação de valores na aplicação da Lei Complementar $n^{\circ}$. 105, de 2001A Constituição Federal de 1988 surgiu num contexto que deve ser lembrado e utilizado como norteador quando se trata da proteção do contribuinte ou dos cidadãos face à atuação estatal, principalmente no âmbito dos direitos e garantias fundamentais, de modo que não se ignore o que está sedimentado no texto constitucional quando se trata de sigilo de dados, bancário e fiscal. 
O FATCA se mostra como o grande expoente dessa tendência mundial de acesso compartilhado de informações entre entes estatais que devem adequar sua legislação interna e para o que não haja conflitos entre os caminhos que o mundo está tomando acerca do acesso de dados e remessa de informações de operações que envolvam a fiscalização tributária em si, de modo que haja maior segurança em nível global seja no que se refere a fluxo de riquezas e combate ao crime organizado.

Por tudo que se viu, seria razoável que o STF adotasse uma posição que ponderasse nossas garantias constitucionais com um posicionamento que não vedasse de forma absoluta aoacesso direto aos dados bancários pelo Fisco, cabendo até uma interpretação da legislação conforme a Constituição para que o acesso a esses dados seja restringido às situações nas quais há indícios ou provas de fraude, crime ou abuso de direito, principalmente, quando relacionados a procedimentos que possam conduzir à comprovação de lavagem de dinheiro obtido através do crime organizado, bem como de operações societárias fraudulentas. 


\section{REFERÊNCIAS}

AZEVEDO, Patricia Anjos. O principio da transparência e a troca de informações entre administrações fiscais. Tese de Mestrado. Faculdade de direito da universidade do porto. 2010. Disponível em: http://www.cije.up.pt/publications/o-principio-da-transparencia. Acesso em $15 / 10 / 2013$.

BARBOSA, Marcio Roberto da Costa. Os paraísos fiscais diante da crise financeira: perspectivas em regimes internacionais. Disponível em: http://www.anpocs.org/portal/index.php?option=com_docman\&task=doc_view\&gid=8714\&Ite mid=429. Acesso em 25/10/2013.

BIANCO, João Francisco. Transparência fiscal internacional. São Paulo, Dialética, 2007. BRASIL. Superior Tribunal de Justiça. REsp 1349363/SP, Rel. Ministro MAURO

CAMPBELL MARQUES, PRIMEIRA SEÇÃO, julgado em 22/05/2013, DJe 31/05/2013. Disponível em:

http://www.stj.jus.br/SCON/jurisprudencia/doc.jsp?livre $=1349363+\& \& b=A C O R \& p=$ false $\& \mathrm{t}=\mathrm{J}$ URIDICO\&l=10\&i=1. Acesso em 15/08/2014.

. Superior Tribunal de Justiça. REsp 1197444/RJ, Rel. Ministro NAPOLEÃO NUNES MAIA FILHO, PRIMEIRA TURMA, julgado em 27/08/2013, DJe 05/09/2013.Disponível em:

http://www.stj.jus.br/SCON/jurisprudencia/toc.jsp?tipo_visualizacao=RESUMO\&livre=119744 $4+\& b=$ ACOR $\&$ thesaurus=JURIDICO. Acesso em 15/08/2014.

SUPREMO TRIBUNAL FEDERAL. Mandado de Segurança $\mathrm{n}^{\circ}$. 22934, Relator(a): Min. JOAQUIM BARBOSA, Segunda Turma, julgado em 17/04/2012, ACÓRDÃO ELETRÔNICO DJe-090 DIVULG 08-05-2012 PUBLIC 09-05-2012.

CARRAZZA, Roque Antonio. Curso de Direito Constitucional Tributário. 29.ed.São Paulo. Malheiros, 2013.

CAVALCANTE, Denise Lucena; FARIAS, Rui Barros Leal; Paraísos fiscais: o liame entre o planejamento fiscal internacional $\mathrm{e}$ as práticas evasivas danosas. Disponível em: http://www.conpedi.org.br/manaus/arquivos/anais/XIVCongresso/195.pdf,

CUNHA JR, Dirley. Curso de Direito Constitucional. 9ª ed. Salvador: Editora Juspodivm, 2011.

ESTELLITA, Heloisa; BASTOS, Frederico Silva. Acordos de troca de informações tributárias precisam ser disciplinados. Disponível em: http://www.conjur.com.br/2014-dez-02/ acordostroca-informacoes -tributarias-disciplinados. Acesso em 10 de mai de 2015.

FARIA, Wilson Rodrigues; ROCHA, Alessandra M Gonsales. O combate internacional à evasão fiscal - como FATCA pode afetar as isntituições financeiras brasileiras. Disponível em: http://whathappensin.com.br/wp-content/uploads/2013/09/artigo1.pdf. Acesso em 20 de abr. de 2014. 
FILHO PANZARINI, Clovis; BELLAN, Daniel Vitor; TONANNI, Fernando et. Al. Estudos avançados de direito tributário. Rio de Janeiro, Campus Elsevier, 2012.

Global Forum on Transparency and Exchange of Information for Tax Purposes . Statement of Outcomes. Disponível em: http://www.oecd.org/tax/transparency/statement-ofoutcomes-gfberlin.pdf. Acesso em 10/04/2015.

Harmful Tax Competition. Disponível em:

http://www.oecd.org/tax/transparency/44430243.pdf. Acesso em 15/10/2013.

\section{Legal institute law. U.S. Code Subtitle A - Income Taxes. Disponível em:} https://www.law.cornell.edu/ uscode/text /26/subtitle-A. Acesso em: 28 de abr. de 2015.

MASON, Frederick Mario. Concorrência fiscal internacional e Paraísos fiscais. Revista do mestrado de direito. Disponível em: http://portalrevistas.ucb.br/index.php/rvmd/article/viewFile/2587/1578. Acesso em 15/10/2013.

PAULSEN, Leandro. Direito tributário constituição e código tributário. 15.ed.São paulo. Livraria do Advogado, 2013.

PERPETUO, Neuza. A CONCORRENCIA FISCAL E OS PARAÍSOS FISCAIS. Disponível em:

http://www.fd.uc.pt/ stavares/FDUC/Arquivo_2009_2010/Entradas/2010/5/1_Ainda_uma_sob erania_fiscal_(9)_files/Neuza.pdf. Acesso em 05/11/2013.

PINTO, Edson. Lavagem de capitais e paraísos fiscais. São Paulo, Atlas, 2007.

SÁ, Luiz Ricardo De Azeredo. STF e a quebra de sigilo bancário pelo fisco. Disponível em: http://www.egov.ufsc.br/portal/conteudo/stf-e-quebra-de-sigilo-banc\%C3\%A1rio-pelo-fisco.

Acesso em 15/10/2013.

SOARES, Roberta Oliveira. Os Sigilos Bancário e Fiscal e o Intercâmbio de Informações Sigilosas.Disponível em:

http://www.cvm.gov.br/port/public/publ/ie_ufrj_cvm/Roberta_Oliveira_Soares.pdf. Acesso em $25 / 10 / 2013$.

Tavolaro, Agostinho Toffoli. O Tratado de Troca de Informações Fiscais Brasil-Estados Unidos - TIEA, em Direito Tributário Internacional Aplicado — vol. VI, Coord. Heleno Taveira Tôrres, São Paulo: Quartier Latin, 2012

TORRES, Heleno. Pluritributação Nacional sobre a renda das empresas. 2.ed. São Paulo, Revista dos Tribunais, 2001.

VALADÃO, Marco Aurélio Pereira ; HENRIQUE, Porto de Arruda. Direitos fundamentais, privacidade, intimidade, sigilos bancário e fiscal, e o consenso internacional. Disponível em: http://www.periodicos.ufc.br/index.php/nomos/article/viewFile/1226/1190. Acesso em:

10/08/2014. 